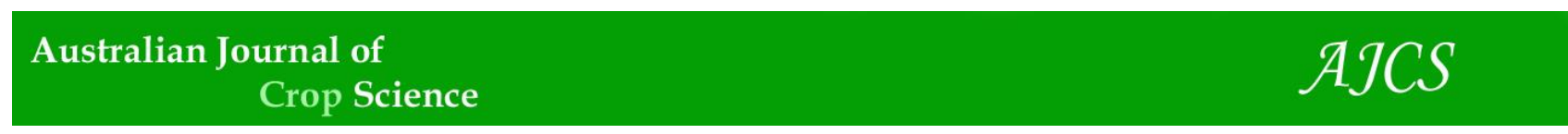

AJCS 13(04):546-551 (2019)

ISSN:1835-2707

doi: 10.21475/ajcs.19.13.04.p1452

\title{
Fruit quality of a traditional pineapple cultivar (Turiaçu) compared to the most popular cultivar (Pérola) in Brazil
}

\author{
Fabrício de Oliveira Reis ${ }^{1 *}$, José Ribamar Gusmão Araujo ${ }^{1}$, Heder Braun ${ }^{1}$, Augusto César Vieira Neves \\ Junior $^{1}$, Anna Paula A Pereira ${ }^{1}$
}

UEMA - Universidade Estadual do Maranhão, NO-1, Maranhão, Brazil

\section{*Corresponding author: fareoli@gmail.com}

\begin{abstract}
Turiaçu is a traditional pineapple cultivar in the state of Maranhão, Brazil, and its fruits have high potential for the fresh fruit market due to consumer acceptance. This cultivar is in the process of domestication, but information on the quality of its fruits and their standards for marketing is scarce. The objective of this study was to evaluate the biometric and chemical characteristics of the Turiaçu pineapple cultivar and the Pérola cultivar, which are grown in the main pineapple producing areas-Turiaçu, and São Domingos do Maranhão-in the state of Maranhão. The fruits were harvested at the green stage to evaluate the following biometric characteristics: fruit weight, infructescence weight, pulp yield, crown, peel and total residues, and base to apex diameter ratio; and the following chemical characteristics - total soluble solids (TSS), total titratable acidity (TTA), and TSS to TTA chemical ratio. The Turiaçu cultivar presented higher fruit and infructescence weights, more cylindrical fruits, and pulp with higher TSS concentration and less acidity, compared to the Pérola cultivar. Fruits of the Turiaçu cultivar had more desirable biometric and chemical qualities for the consumer market - they were large, cylindrical, sweet, and with low acidity-, compared to those of the Pérola cultivar.
\end{abstract}

Keywords: Ananas comosus var. comosus (L.) Merril; postharvest characterization; humid tropic; Turiaçu cultivar; Pérola cultivar. Abbreviations: TPC _ Turiaçu pineapple cultivar; PPC _ Pérola pineapple cultivar; TSS _ total soluble solids; TTA _ total titrable acidity; MA _ state of Maranhã; FW _ fruit weight; IW infructescence weight; CR _ crown ratio; DM _ diameter of the infructescence mid region; $D R$ _ diameter ratio; $P Y$ _ pulp yield; $C_{R}$ crown residue; $P_{R}$ _ peel residue; $T_{R}$ - total residue; $C V$ _ coefficient of variation; $\mathrm{Cl}_{-}$confidence interval; $t_{-} t$ calculated by the t-Student test; $\mathrm{Pr}>t_{c_{-}}$calculated probability; FAPEMA Foundation for the Support of Scientific Research and Development of the State of Maranhão; CAPES _ Coordination for the Improvement of Higher Education Personnel; PNPD _ National Postdoctoral Program; CNPq _ Brazilian National Council for Scientific and Technological Development.

\section{Introduction}

Pineapple (Ananas comosus (L.) Merr.) fruits, in terms of total volume, is the most important in Brazil (OECD/FAO, 2015). Brazil is the world's second largest pineapple producer, with a production $9.24 \%$ lower than Costa Rica in 2014 (FAO, 2017). According to the Turiaçu Cooperative of Pineapple and Other Fruit Producers (COOPPFRUT), the Turiaçu pineapple producing region has approximately 200 hectares and 60 associated producers and represents $14.41 \%$ of the total are planted with pineapple (all cultivars) in the state of Maranhão, Northeast region of Brazil (IBGE, 2017).

The world's commercial pineapple production consists of crops with the Smooth Cayenne, Pérola, Queen, Singapore, Española Roja and Perolera cultivars. Several local cultivars and wild populations of pineapple from the genus Ananas occur in some places of Latin America, including Brazil (Reinhardt et al., 2000). The best-known pineapple cultivar in Brazil is the Pérola, and in the world, it is the Smooth Cayenne (Miguel et al., 2007). The most planted pineapple cultivar in the state of Maranhão (MA) is the Pérola, but the
Turiaçu cultivar has been standing out/ gaining importance in the local market. The municipality of São Domingos do Maranhão MA, has the largest area planted with pineapple in the state, approximately 800 ha, predominantly with the Pérola cultivar, followed by the municipality of Turiaçu that has approximately 150 ha, predominantly with the Turiaçu cultivar (Araujo et al., 2012).

The Pérola cultivar was selected by indigenous people of Brazil (Viana et al., 2013). This cultivar produces cylindrical fruits that are slightly conical at the apex, have yellowishgreen peel, and juicy pulp that is pale-yellow or white in color. Chemically, the fruits present 13.1 to 13.7 oBrix total soluble solids (TSS), total titratable acidity (TTA) of 0.42 to $0.73 \mathrm{~g}$ of citric acid per 100g of pulp and 18.19:32.60 TSS to TTA chemical ratio (Andrade et al., 2015; Berilli et al., 2014; Araujo et al., 2012; Brito et al., 2008).

The Turiaçu cultivar was selected by family farmers from Turiaçu, MA. This cultivar is in the process of domestication and improvement of its production system and field and post-harvest surveys started in 2006 . The Turiaçu cultivar is 
considered, empirically, resistant to fusariosis by the regional producers. Fusariosis is a disease that causes serious damage to Pérola pineapple fruits grown in the central region of Maranhão (Araujo et al., 2012).

According to Fassinou Hotegni et al. (2016), the quality of the pineapple fruits is essential for their acceptance by consumers; the fruits need to reach minimum requirements-weight of at least $0.7 \mathrm{~kg}, 0.5: 1.5$ crown to infructescence length ratio; and pulp TSS of at least 12 oBrix. These authors found that consumers find it difficult to detect these quality characteristics.

The consumer market first evaluates the aspect and shape of the fruits; and, after the fruit is purchased, the consumer evaluates the flavor, aroma, and texture. Information in the scientific literature on the quality standards to market fruits of the Turiaçu cultivar is scarce. Thus, the hypothesis assessed in this study that the fruits of the Turiaçu pineapple cultivar has better biometric and chemical qualities than those of the Pérola cultivar, which is the most planted and marketed pineapple cultivar in Brazil and in the state of Maranhão. Thus, the objective of this study was to evaluate the biometric and chemical characteristics of the Turiaçu and Pérola pineapple cultivars, which are grown in the main pineapple producing areas-Turiaçu and São Domingos do Maranhão-in the state of Maranhão, Brazil.

\section{Results}

\section{Weather conditions}

The average temperature in Turiaçu, MA (collection location of the Turiaçu cultivar) was higher than that in São Domingos do Maranhão, MA (collection location of the Pérola cultivar) during the two years of the pineapple crop development, except in September 2011 and 2012, and October 2011. Turiaçu had the highest cumulative monthly precipitation. Data of average temperatures and accumulated precipitations are presented in Figure 1.

The variation of experimental data was expressed by the coefficient of variation (CV), which is essential for evaluating the precision of the results. The $\mathrm{CV} \leq 10 \%$ is usually considered low, $10<\mathrm{CV} \leq 20 \%$ are moderate, $20<\mathrm{CV} \leq 30 \%$ are high, and CV $>30 \%$ are very high (Gomes, 1990). However, this general classification does not consider agronomic aspects, the characteristics under evaluation, weather conditions, or growing cycles (Scapim et al., 1995).

\section{Biometric quality}

The fruits of the Turiaçú cultivar had greater total fruit weight (FW), infructescence weight (IW) and crown residue $\left(C_{R}\right)$ than those of the Pérola cultivar. The Turiaçu cultivar had crown ratio (CR) $81 \%$ higher and diameter ratio (DR) $11 \%$ lower than the Pérola cultivar (Table 1).

However, the peel residue $\left(P_{R}\right)$, total residue $\left(T_{R}\right)$, pulp yield (PY), and diameter of the infructescence mid region (DM) of the fruits of both cultivars were similar. The $P_{R}$ of the Turiaçú (233\%) and Pérola (569\%) were higher than the $C_{R}$ (Table 1).

\section{Chemical quality}

The fruits of the Turiaçu cultivar were sweeter ( $22 \%$ of TSS, and $\sim 72 \%$ of TSS:TTA) and had less acidity ( $30 \%$ TTA) than those of the Pérola cultivar (Table 2). The significant statistical difference between the means of TSS and TSS:TTA of the two evaluated pineapple cultivars is shown by the calculated $t$ value (Table 2 ). The calculated value of the $t$ Student test indicates the differences between the two means-observed difference between the sample means and expected difference between population means, if $\mathrm{H}_{0}$ is true-in terms of the standard deviation, i.e., the greater the difference between the means of the treatments, the greater the chance of facing different treatments. The difference between the two TSS means was 16.10, and between the two TSS: TTA means was11.15, in terms of standard deviation. These results showed that the fruits of the traditional cultivar of Maranhão (Turiaçu cultivar) had better chemical qualities, when compared to those of the most planted pineapple cultivar in Brazil and in the state of Maranhão (Pérola cultivar).

\section{Discussion}

The edaphoclimatic conditions for the plant development directly affect the biometric and chemical characteristics of the fruits. Although the fruits of each cultivar were collected from sites with different soil and climatic conditions, the characteristics of the fruits found in this study represented those of the fruits currently available on the market. Each municipality has traditionally grown only one cultivar and the growing of the two cultivars in the same region is practically non-existent. The FW and IW of the Turiaçu cultivar were higher than those of the Pérola cultivar (Table 1 ), but both cultivars were within the same classification (Class 2, fruits weighing between $1.2 \mathrm{~kg}$ and $1.5 \mathrm{~kg}$ ), according to the MAPA Normative Instruction (Brasil, 2002). High-weight fruits are highly desired by rural producers and the consumer market. Araujo et al. (2012) reported FW of 1.620 (Turiaçu) and $1.650 \mathrm{~kg}$ (Pérola cultivar), and IW of 1.558 (Turiaçu) and $1.566 \mathrm{~kg}$ (Pérola cultivar). The results of FW in the present study presented an average difference of approximately $200 \mathrm{~g}$, compared to those of Araujo et al. (2012). However, Fassinou Hotegni et al. (2016) evaluated a local pineapple cultivar (Sugarloaf) in West Africa, believed to be the Pérola cultivar, and found $1.240 \mathrm{~kg} \mathrm{FW}$. This result is similar to that found for the Pérola cultivar in the present study. On the other hand, Berilli et al. (2014) reported 0.952 $\mathrm{kg} \mathrm{FW}$, which is lower than that found for the two cultivars evaluated in the present study. These results show the high variability of the FW. This variable depends on several factors that occur during crop development, such as soil fertility, water availability, and temperatures (Chitarra and Chitarra, 2005). Caetano et al. (2015) evaluated seven pineapple genotypes-EC-105 and EC-93 hybrids; and BRS Vitória, BRS Imperial, Pérola, Gold (MD 2) and Smooth Cayenne cultivars. The Smooth Cayenne had $1.483 \mathrm{~kg} \mathrm{FW}$ and the Gold (MD-2) had $1.380 \mathrm{~kg} \mathrm{FW}$; these results are similar to those found for the Turiaçu cultivar in the present study. However, the FW of the EC-93 $(1.988 \mathrm{~kg})$ and EC-105 $(1.751 \mathrm{~kg})$ hybrids were higher than that found for the Turiaçu in the present study. The FW of the Pérola (1.266 kg) was similar to that found for the same cultivar in the present study. Reinhardt et al. (2000) reported FW of 1,000 to 1,500 $\mathrm{g}$ for the Pérola cultivar. The differences in IW between the two cultivars followed the same trend as the FW. 
Table 1. Biometric characteristics of Turiaçu and Pérola pineapple cultivars. $n \_26$, mean \pm standard error of the mean and confidence interval (Cl).

\begin{tabular}{llllllll}
\hline Variable & Turiaçu & $\mathrm{Cl}(95 \%)$ & Pérola & $\mathrm{Cl}(95 \%)$ & $t_{\mathrm{c} ; 0.05}$ & $\mathrm{Pr}>t_{\mathrm{c}}$ & $\mathrm{CV} \%$ \\
\hline $\mathrm{FW}(\mathrm{kg})$ & $1.41 \pm 0.03 \mathrm{a}$ & $1.36-1.47$ & $1.25 \pm 0.03 \mathrm{~b}$ & $1.19-1.31$ & 4.17 & 0.0001 & 12.50 \\
$\mathrm{IW},(\mathrm{kg})$ & $1.328 \pm 0.027 \mathrm{a}$ & $1.272-1.384$ & $1.207 \pm 0.028 \mathrm{~b}$ & $1.148-1.265$ & 3.08 & 0.0033 & 12.11 \\
$\mathrm{DR}$ & $0.85 \pm 0.03 \mathrm{a}$ & $0.80-0.90$ & $0.47 \pm 0.02 \mathrm{~b}$ & $0.43-0.50$ & 12.64 & 0.0001 & 33.19 \\
$\mathrm{DM},(\mathrm{cm})$ & $10.18 \pm 0.07 \mathrm{a}$ & $10.03-10.33$ & $10.08 \pm 0.09 \mathrm{a}$ & $9.90-10.25$ & 0.92 & 0.3643 & 3.99 \\
$\mathrm{CR}$ & $1.26 \pm 0.03 \mathrm{~b}$ & $1.19-1.32$ & $1.41 \pm 0.04 \mathrm{a}$ & $1.33-1.48$ & 3.13 & 0.0029 & 14.00 \\
$\mathrm{PY}(\%)$ & $74.19 \pm 0.68 \mathrm{a}$ & $72.78-75.59$ & $76.02 \pm 0.80 \mathrm{a}$ & $74.38-77.66$ & 1.74 & 0.0873 & 5.14 \\
$\mathrm{C}_{R}(\%)$ & $6.00 \pm 0.15 \mathrm{a}$ & $5.69-6.32$ & $3.12 \pm 0.16 \mathrm{~b}$ & $2.78-3.47$ & 12.92 & 0.0001 & 42.33 \\
$\mathrm{P}_{\mathrm{R}}(\%)$ & $19.81 \pm 0.70 \mathrm{a}$ & $18.37-21.25$ & $20.86 \pm 0.84 \mathrm{a}$ & $19.14-22.59$ & 0.96 & 0.3394 & 22.38 \\
$\mathrm{~T}_{R}(\%)$ & $25.81 \pm 0.68 \mathrm{a}$ & $24.41-27.22$ & $23.98 \pm 0.80 \mathrm{a}$ & $22.34-25.62$ & 1.74 & 0.0873 & 17.70 \\
\hline
\end{tabular}

Values followed by the same letters on a line are not significantly different at $\mathrm{P} \_0.05$ according to the $t$-Student test. $\mathrm{Cl}$ confidence interval at $95 \%$ probability; $t \quad t$ calculated by the $t$-Student test;

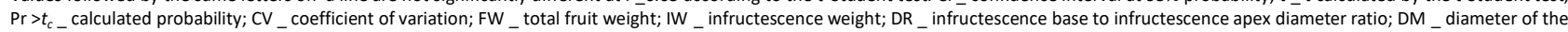
infructescence mid region; $C R_{-}$crown to infructescence length ratio; $P_{-}$pulp yield; $C_{R_{-}}^{-}$crown residue; $P_{R_{-}}$peel residue; $T_{R_{-}}$total residue.



Fig 1. Monthly mean temperatures (A) and accumulated precipitation (B) throughout the two years of development of the pineapple crops with Turiaçu and Pérola cultivars, in Turiaçu and São Domingos do Maranhão, Brazil (NUGEO/UEMA, 2017). 
Table 2. Means of the chemical characteristics of Turiaçu and Pérola pineapple cultivars, $n \_9$; Mean \pm standard error of the mean.

\begin{tabular}{llllllll}
\hline Variable & Turiaçu & $\mathrm{Cl}, 95 \%$ & Pérola & $\mathrm{Cl}, 95 \%$ & $t_{\mathrm{c} ; 0,05}$ & $\mathrm{Pr}>t_{c}$ & $\mathrm{CV} \%$ \\
\hline TSS & $15.2 \pm 0.05 \mathrm{a}$ & $15.12-15.34$ & $12.5 \pm 0.17 \mathrm{~b}$ & $12.07-12.83$ & 16.10 & 0.0001 & 10.64 \\
TTA & $0.545 \pm 0.013 \mathrm{~b}$ & $0.514-0.576$ & $0.775 \pm 0.032 \mathrm{a}$ & $0.701-0.849$ & 6.62 & 0.0001 & 20.98 \\
TSS:TTA & $28.10 \pm 0.72 \mathrm{a}$ & $26.44-29.76$ & $16.32 \pm 0.77 \mathrm{~b}$ & $14.53-18.10$ & 11.15 & 0.0001 & 29.01 \\
\hline
\end{tabular}

Values followed by the same letters on a line are not significantly different at $\mathrm{P}_{-} 0.05$ according to the $\mathrm{t}$-Student test. $\mathrm{Cl}_{-}$confidence interval at $95 \%$ probability; $t_{-} t$ calculated by the $t-S_{-}$tudent test;

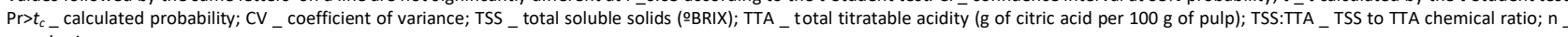
sample size.

The cultivars had big differences in $C R$ and $C_{R}$, which was shown by the coefficient of variation (CV). The CV was high for all the variables used to evaluate the differences between the crowns of the two cultivars.

The fruits of the Turiaçú cultivar had practically 2 -fold the $C R$ and $C_{R}$ (Table 1) of the Pérola cultivar. These are undesirable characteristics for fruits intended for fresh consumption and industry. According to Fassinou Hotegni et al. (2016), the CR should be between 0.5 and 1.5. The fruits of both cultivars evaluated were within this range and, thus, they were suitable for fresh consumption.

The two pineapple cultivars had no significant difference in $\mathrm{P}_{\mathrm{R}}\left(p_{\text {_ }} 0.3394 ; \mathrm{CV} \%_{-} 22.38\right)$ and $\mathrm{T}_{\mathrm{R}}\left(p_{-} 0.0875 ; \mathrm{CV} \%\right.$ 17.70). This denotes that the crown has slight importance when evaluating the fruit quality, since the peel was the main source of residue for both cultivars $-77 \%$ (Turiaçu) and $87 \%$ (Pérola).

The Brazilian population faces problems with malnutrition and food waste. Peel residues of pineapple fruits can be used to produce flour that can be added to different types of foods as an alternative to combat malnutrition and improve the income of families in the state of Maranhão. According to Leonel et al. (2014), flours from pineapple residues can be used as sources of insoluble fibers. Moreover, pineapple residues can generate other products, which can have high added values (Carvalho et al., 2016; Lima et al., 2016), such as the use of pineapple peel and crown residues to produce vinegar (Roda et al., 2017) or biofuel (Khedkar et al., 2017). The two cultivars had no significant differences in DM ( $p$ 0.3643 ), however, the Turiaçu cultivar had the lowest DR ( $p$ - 0.0029) (Table 1). DR is the main parameter for agroindustry because it indicates the shape of the infructescence. A DR close to 1.00 indicates infructescence with a more cylindrical shape. A high DR indicates that the infructescence has a conical shape. The DR showed that the infructescence of the Turiaçu cultivar fruits was more cylindrical than that of the Pérola cultivar. This indicates that fruit of the Turiaçu cultivar is probably suitable for industrial use.

The DM of the cultivars evaluated was similar to that of the Gold $(11.8 \mathrm{~cm})$, Pérola $(10.5 \mathrm{~cm})$, EC-93 $(10.2 \mathrm{~cm})$ and Vitória $(10.8 \mathrm{~cm})$ genotypes (Berilli et al., 2014). These data and their comparison with data from other studies show the viability for fresh fruit marketing of the Turiaçu, since this cultivar does not present DM lower than those of other varieties previously studied.

The two evaluated cultivars showed no significant differences $\left(p_{-}{ }_{0.0873)}\right.$ for the PY (Table 1$)$; this result was similar to that found by Andrade et al. (2015) for the Vitoria cultivar $(74.97 \%)$, but they found lower PY for the Pérola cultivar fruits (69.91\%). These same authors reported the Vitória cultivar PY as one of the characteristics that contributes to the possible use of its fruits by industry and for fruit fresh marketing; this fact reinforces the suitability of the Turiaçu cultivar for fresh marketing.
The fruits of the Turiaçu cultivar had greater quality than those of the Pérola cultivar. The means of all the evaluated chemical characteristics were significantly different between the two evaluated cultivars (Table 2). According to Miguel et al. (2007), consumers of fresh pineapple fruits prefer sweet tasting fruits, withhigh TSS and high chemical ratio, and low acidity-low TTA. The authors denote that high acidity is the main cause of complaints after purchasing the fruit.

The fruit pulp TSS of the Turiaçu was $22 \%$ higher than that of the Pérola (Table 1). These are similar results to those found for the IAC-Gomo-de-Mel (15.7 ${ }^{\circ}$ Brix) and Gold (14.8 $\left.{ }^{\circ} \mathrm{Brix}\right)$ cultivars (Berilli et al., 2014). The fruit pulp TSS of the Pérola cultivar (13.2을 $)$ was lower than that reported by Berilli et al. (2014) and Brito et al. (2008).

The fruit pulp TTA of the Turiaçu cultivar was lower than that of the Pérola; this is a highly desirable characteristic. Fruits of the Turiaçu had lower acidity than those of the IACGomo-de-Mel ( $0.67 \mathrm{~g}$ citric acid per $100 \mathrm{~g}$ of pulp), Smooth Cayenne $(0.85 \mathrm{~g}$ citric acid per $100 \mathrm{~g}$ pulp) Vitória $(0.81 \mathrm{~g}$ citric acid per $100 \mathrm{~g}$ pulp), and EC-93 (0.63 g citric acid per $100 \mathrm{~g}$ pulp) genotypes. The fruit acidity of the Turiaçu cultivar was slightly higher compared to that of the Gold cultivar (0.52 g citric acid per $100 \mathrm{~g}$ pulp) (Brito et al., 2008; Berilli et al., 2014).

The highest TSS and lowest TTA of the Turiaçu cultivar are the main reasons for its greater preference by the consumer market; this combination increases the fruit pulp chemical ratio (TSS:TTA) of this cultivar. The fruit pulp of the Turiaçu was sweeter than that of the Pérola cultivar. The pulp chemical ratio of the Turiaçu cultivar was almost 1.72 -fold the chemical ratio of the Pérola. The chemical ratio represents the effects of acidity on the sweet taste-the higher the chemical ratio, the greater the sweetness; this property can also be used as a maturation index (Chitarra and Chitarra, 2005).

The fruit pulp of the Turiaçu cultivar had a higher chemical ratio than that reported by other studies on the Pérola (22.17 to 18.19), Vitória (20.14 to 19.80), and EC-93 (19.12) genotypes. The Turiaçu had a slightly lower chemical ratio compared with the Gold cultivar (28.46); this indicates that both cultivars have similar sweetness (Berilli et al., 2014; Andrade et al., 2015).

Although there is no classification for the chemical composition of pineapple fruits, the MAPA Normative Instruction (Brasil, 2002) establishes that fruit pulps with TSS equal to or lower than 12.0 oBrix are unripe fruits, and therefore unfit for fresh marketing. Thus, all the evaluated fruits of the Turiaçu and Pérola cultivars were suitable for fresh marketing.

The possible industrial use of the Turiaçu cultivar denotes the need for advanced research on the reuse of its residues, not only the peel, but also the crown, since these residues represent about $25 \%$ of the fruit weight. Research on the technological suitability to produce pulp, juice, nectar, and 
other products is necessary to exploit the full potential of this traditional pineapple cultivar of the state of Maranhão.

\section{Materials and Methods}

\section{Location and sample collection}

Twenty-six pineapple fruits of the Turiaçu cultivar from a commercial orchard in Turiaçu, in the state of Maranhão (MA), Brazil (0139'48"S, 4522'18'W, and altitude of 44.06 $\mathrm{m})$, and 26 pineapple fruits of the Pérola cultivar from a commercial orchard in São Domingos do Maranhão MA (05034'48'S, 4422'59"W, and altitude of $210 \mathrm{~m}$ ) were collected in October 2012 and evaluated. Figure 1 shows the average temperature and accumulated precipitation over the two years of crop development in the two producing areas.

The fruits were harvested with the peduncle and were green in color (Brasil, 2002), which is an aspect used to determine the pineapple harvest point by farmers from both producing locations. The fruits were transported in plastic boxes to the Plant Science and Postharvest Laboratory of the State University of Maranhão. The fruits were then selected and homogenized according to quality attributes, such as absence of injuries and diseases. The fruits were then washed in running water, sanitized in a $0.01 \%$ sodium hypochlorite solution for approximately 60 seconds, and placed on a previously sanitized bench to dry at room temperature.

\section{Biometric analysis}

The biometric characteristics evaluated were total fruit weight (FW; kg); infructescence weight (IW; kg); crown ratio (CR)-crown to infructescence length ratio; diameter of the infructescence mid region (DM; $\mathrm{cm}$ ); diameter ratio (DR)infructescence base to infructescence apex diameter ratio; pulp yield (PY; \%)-pulp to total fruit weight ratio; crown residue $\left(C_{R} ; \%\right)$-crown to total fruit weight ratio; peel residue $\left(\mathrm{P}_{\mathrm{R}} ; \%\right)$ - peel to total fruit weight ratio; total residue $\left(T_{R} ; \%\right)-$ fruit residues to total fruit weight ratio. The fruit dimensions were measured with a caliper ruler, and the fruits were weighed using semi-analytical scales.

\section{Chemical analysis}

The fruits were evaluated taking into account fresh consumption standards. The fruit central cylinder was considered part of the infructescence pulp. After biometric evaluation, 15 fruits were randomly chosen to characterize and quantify the pulp chemical composition, and three samples-composed of five fruits each-were formed. Three approximately $1 \mathrm{~cm}$ thick pulp slices -one from the basal third, one from the mid region, and on from the apical region of the fruit- were taken from each fruit of these samples. The three slices of the five fruits were processed and homogenized in a stainless-steel grinder for approximately 5 minutes, for each sample. The chemical quality of these pulps was then evaluated by determining total soluble solids concentration (TSS; - $B$ Brix), total titratable acidity (TTA; $g$ citric acid per $100 \mathrm{~g}$ pulp), and pulp chemical ratio-TSS to TTA ratio.
The TSS content was determined in a Pal-01 Digital Pocket refractometer, according to the ISO 2173:2003 standardization (International Organization For Standardization, 2003). A solution of $0.1 \mathrm{~N}$ sodium hydroxide was titrated using $1 \%$ phenolphthalein indicator to determine the ATT, according to the methodology proposed by the Analytical Norms of the Adolf Lutz Institute (Zenebon et al., 2008). All determinations of chemical characteristics were performed in triplicate.

\section{Statistical analysis}

The Turiaçu cultivar was compared to the Pérola cultivar using the means of all variables evaluated, by the bilateral tStudent test for non-paired samples. A confidence interval of $95 \%$ was used, and the results were presented as means \pm standard error of the mean. All statistical analyzes were performed at $5 \%$ probability in the MINITAB ${ }^{\circ}$ 17.1.0 statistical software $\left(\right.$ MINITAB $\left.^{\circledR}, 2014\right)$.

\section{Conclusion}

The Turiaçu pineapple cultivar has larger, more cylindrical, sweeter, and less acidic fruits than the Pérola cultivar which indicate that these fruits have more desirable characteristics for the consumer market.

\section{Acknowledgements}

The authors thank the Foundation for the Support of Scientific Research and Development of the State of Maranhão (FAPEMA) for funding this project; the Coordination for the Improvement of Higher Education Personnel (CAPES) for financial support through the scholarship granted by the National Postdoctoral Program (PNPD), and the Brazilian National Council for Scientific and Technological Development (CNPq) for granting scholarships to the students involved in this project.

\section{References}

Andrade $M$ das $G$ dos $S$, Silva $S$ de $M$, Soares $L G$, Dantas $A L$, Lima RP, Souza ASB de, Melo R de S (2015) Aspectos da qualidade de infrutescências dos abacaxizeiros 'Pérola' e 'Vitória'. Rev AGROTEC, 36, 96-102.

Araujo JRG, Aguiar Júnior RA, Chaves AMS, Reis FDO, Martins MR (2012) Abacaxi 'Turiaçu': cultivar tradicional nativa do Maranhão. Rev Bras Frut, 34, 1270-1276.

Berilli S da S, Freitas S de J, Santos PC dos, Oliveira JG De, Caetano LCS (2014) Avaliação da qualidade de frutos de quatro genótipos de abacaxi para consumo in natura. Rev Bras Frut, 36, 503-508.

Brasil (2002) 'Ministério da Agricultura e Abastecimento. Regulamentos Técnicos de Identidade e de Qualidade para a classificação de Abacaxi, Uva Fina de Mesa e Uva Rústica.' (Diário Oficial da União: Brazil).

Brito CAK de, Siqueira PB, Pio TF, Bolini HMA, Sato HH (2008) Caracterização físico-química, enzimática e aceitação sensorial de três cultivares de abacaxi. R Bras Tecnol Agroindustr, 2, 01-14. 
CAETANO LCS, VENTURA JA, BALBINO JMDS (2015) Comportamento de genótipos de abacaxizeiro resistentes à fusariose em comparação a cultivares comerciais suscetíveis. Rev Bras Frut, 37, 404-409.

Carvalho S, Pires CC, Wommer TP, Lopes JF, Mônego CO, Pilecco VM (2016) Economicidade e desempenho produtivo de cordeiros confinados submetidos a dietas com resíduos agroindustriais. Ci Anim Bras, 17, 36-44.

Chitarra MIF, Chitarra AB (2005) 'Pós-colheita de frutas e hortaliças: fisiologia e manuseio.' (Ufla - Universidade Federal De Lavras: Lavras).

FAO (2017) Food and Agriculture Organization of the United Nations. FAOSTAT. www.fao.org/faostat.org.

Fassinou Hotegni VN, Lommen WJM, Agbossou EK, Struik PC (2016) Understanding the effects of slip pruning on pineapple fruit quality. Acta Hortic, 1111, 231-240.

Gomes FP (1990) 'Curso de Estatística Experimental.' (Livraria Nobel S.A., Editora - Distribuidora: Piracicaba, São Paulo, Brasil)

IBGE (2017) Instituto Brasileiro de Geografia e Estatística. http://www.sidra.ibge.gov.br.

International Organization For Standardization (2003) ISO 2173:2003 (E) Fruits and vegetable products Determination of soluble solids - Refractometric method.

Khedkar MA, Nimbalkar PR, Gaikwad SG, Chavan P V., Bankar SB (2017) Sustainable biobutanol production from pineapple waste by using Clostridium acetobutylicum B 527: Drying kinetics study. Bioresour Technol, 225, 359366.

Leonel S, Leonel M, Sampaio AC (2014) Processamento de frutos de abacaxizeiro cv smooth cayenne: perfil de açúcares e ácidos dos sucos e composição nutricional da farinha de cascas. Rev Bras Frut, 36, 433-439.

Lima LR, Cruz JV da, Hazoff Junior W, Soto FRM (2016) Análise Econômica de um Sistema de Gestão Compartilhada de Resíduos Sólidos Oriundos de uma Indústria de Alimentos. Rev Agro Amb, 9, 917-933.
Miguel ACA, Spoto MHF, Abrahão C, Silva PPM da (2007) Aplicação do método QFD na avaliação do perfil do consumidor de abacaxi 'Pérola'. Ciênc Agrotec, 31, 563569.

MINITAB ${ }^{\circledR}$ (2014) MINITAB ${ }^{\circledR}$ 17.1.0.

NUGEO/UEMA (2017) Núcleo Geoambiental/Universidade Estadual do Maranhão. http://www.nugeo.uema.br/.

OECD/FAO (2015) 'Food and Agriculture Organization of the United Nations. OECD-FAO Agricultural Outlook 20152024.' (O Publishing, Ed.). (OECD Publishing: Paris).

Reinhardt DH, Souza LF da S, Cabral JRS (2000) 'Abacaxi. Produção: aspectos técnicos.' (Embrapa Comunicação para Transferência de Tecnologia: Brasília - DF).

Roda A, Lucini L, Torchio F, Dordoni R, De Faveri DM, Lambri $M$ (2017) Metabolite profiling and volatiles of pineapple wine and vinegar obtained from pineapple waste. Food Chem, 229, 734-742.

Scapim CA, Carvalho CGP de, Cruz CD (1995) Uma proposta de classificação dos coeficientes de variação para a cultura do milho. Pesqu Agropec Bras, 30, 683-686.

Viana EDS, Reis RC, Jesus JL De, Junghans DT, Souza FVD (2013) Caracterização físico-química de novos híbridos de abacaxi resistentes à fusariose. Ciênc Rural, 43, 11551161.

Zenebon O, Pascuet NS, Tiglea P (2008) 'Métodos fídicoquímicos para análise de alimentos.' (Instituto Adolfo Lutz: São Paulo). 